\title{
TAF4 wt Allele
}

National Cancer Institute

\section{Source}

National Cancer Institute. TAF4 wt Allele. NCI Thesaurus. Code C52605.

Human TAF4 wild-type allele is located in the vicinity of 20q13.33 and is approximately 91

$\mathrm{kb}$ in length. This allele, which encodes transcription initiation factor TFIID subunit 4 protein, plays a role in the potentiation of transcriptional activation by retinoic acid, vitamin D3 and thyroid hormone. 